PDFlib PLOP: PDF Linearization, Optimization, Protection

Page inserted by evaluation version www.pdflib.com - sales@pdflib.com 


\title{
HL-60 Cell Differentiation and Osteopontin Expression
}

\author{
JANICE E. BERRY,,$^{a, d}$ MARTHA J. SOMERMAN, $, a, b$ \\ ZHILA KHALKHALI-ELLIS, ${ }^{c}$ PHIL OSDOBY, ${ }^{c}$ AND \\ ROBERT U. SIMPSON ${ }^{b}$ \\ ${ }^{a}$ Department of Periodontics/Prevention/Geriatrics \\ ${ }^{b}$ Department of Pharmacology \\ University of Michigan \\ Ann Arbor, Michigan 48109 \\ ${ }^{c}$ Department of Biology \\ and \\ Division of Bone and Mineral Disease \\ Washington University \\ St. Louis, Missouri 63130
}

\section{INTRODUCTION}

HL-60 cells, a human promyelocytic leukemic cell line, grow in suspension, but when induced to differentiate along the monocyte pathway they adhere to tissue culture plates and undergo morphological changes. ${ }^{1,2}$ In contrast, when HL-60 cells are induced to differentiate along the granulocyte pathway cells remain in suspension. There is increasing evidence that adhesion molecules and their associated receptors play a key role in regulating numerous biological and pathological events, including cell differentiation. ${ }^{3}$ Adhesion molecules either increase or decrease depending on cell type during, or as a result of, differentiation. ${ }^{4-7}$ Also, they and their associated cell surface receptors are expressed in a unique fashion during development, both temporally and spatially, suggesting a role for such molecules in cell differentiation, ${ }^{8-10}$ although the precise roles for adhesion molecules in these events remain to be determined. We hypothesized that differentiation of HL-60 cells along the monocyte/macrophage pathway is related to increased expression of specific adhesion molecules and integrin receptors. Furthermore, such adhesion molecules would not be regulated in the same fashion during differentiation along the granulocyte pathway.

\section{METHODS}

HL-60 cells obtained from ATCC were maintained in RPMI, and media of test cultures were treated with phorbol 12-myristate 13-acetate (PMA), a monocyteinducing agent, at a concentration of $1.5 \mathrm{nM}$ in ethanol, retinoic acid (RA), a granulocyte-inducing agent, at a concentration of $10^{-5} \mathrm{M}$ in ethanol, or an equiva-

${ }^{d}$ Correspondence: Ms. Janice E. Berry, Department of Periodontics/Prevention/ Geriatrics, University of Michigan, 1011 N. University Ave., Ann Arbor, MI 48109-1078. 
lent amount of ethanol alone. Flasks were harvested at 6, 24, 48, and 72 hours after treatment, and RNA was isolated.

For Northern analysis, total RNA ( $30 \mu \mathrm{g} /$ lane) was denatured and electrophoresed on a $1.2 \%$ agarose gel containing $18 \%$ of a $37 \%$ formaldehyde solution. RNA was transferred to a nylon membrane and UV cross-linked. The membrane was probed sequentially with $\alpha^{32}$-P dCTP-labeled cDNAs specific for $\alpha_{\mathrm{v}}$ integrin, osteopontin (OPN) and 18S/28S RNA.

ELISA analysis was performed using partially purified monoclonal antibodies to osteoclast-specific cell surface markers $121 \mathrm{~F}$ and $75 \mathrm{~B}$. ELISA values were normalized for total sample protein.

\section{RESULTS}

Cells exposed to PMA showed a dramatic change in morphology, associated with adhesion, when compared to cells treated with RA or vehicle. As seen in TABLE 1, nearly $100 \%$ of PMA-treated cells were attached to flasks by $24 \mathrm{hr}$ of treatment, while cells treated with vehicle or RA continued to grow in suspension over time.

Northern analysis showed an induction of OPN mRNA with as little as $6 \mathrm{hr}$ of PMA treatment. OPN levels peaked at $24 \mathrm{hr}$ of treatment, and levels remained high for further time points. Levels of $\alpha_{\mathrm{v}}$ mRNA also increased with PMA treatment, but this increase occurred more slowly with continued increase in expression up to $72 \mathrm{hr}$. This result contrasted with Northern analysis of control and RAtreated cells (FIG. 1), where no OPN or $\alpha_{\mathrm{v}}$ mRNA could be detected after $48 \mathrm{hr}$ of treatment.

Induction of $121 \mathrm{~F}$ and $75 \mathrm{~B}$, osteoclast-specific cell-surface antigens, with PMA treatment paralleled increases in mRNA levels of OPN and $\alpha_{\mathrm{v}}$.

\section{CONCLUSIONS}

OPN levels peak at approximately $24 \mathrm{hr}$ following induction of differentiation along the monocyte/macrophage pathway. In contrast, levels of $\alpha_{v}$ integrin increase more gradually. Differentiation along the granulocyte pathway resulted in no apparent induction of OPN or $\alpha_{v}$, and cells did not adhere to flasks. An increase in osteoclast-specific cell-surface antigens accompanied adhesion molecule induction.

TABLE 1. Effects of Agents on Cell Attachment In Vitro ${ }^{a}$

\begin{tabular}{lcccc}
\hline & \multicolumn{4}{c}{ \% Adherent Cells } \\
\cline { 2 - 5 } Treatment & $6 \mathrm{Hr}$ & $24 \mathrm{Hr}$ & $48 \mathrm{Hr}$ & $72 \mathrm{Hr}$ \\
\hline Control & 0 & 0 & 0 & 0 \\
RA & 0 & 0 & 0 & 0 \\
PMA & 0 & 75 & 90 & 93 \\
\hline
\end{tabular}

"Cells were plated at a concentration of $2 \times 10^{5}$ cells $/ \mathrm{ml}$, and treated with retinoic acid (RA), $10^{-5} \mathrm{M}, 12$-myristate 13-acetate (PMA), $1.5 \mathrm{nM}$ or ethanol (control) and percent of cells attached versus suspended determined at designated times by Coulter Counter. 

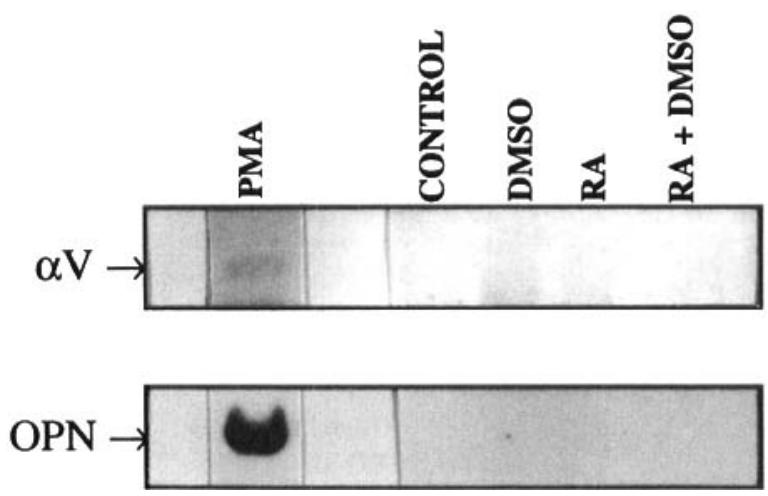

FIGURE 1. Effect of experimental treatments on mRNA levels of $\alpha_{v}$ and OPN in HL-60 cells. Northern hybridization of RNA from cells treated with retinoic acid or PMA. The first lane shows mRNA levels with PMA treatment for $48 \mathrm{hr}$, which is compared with control and 48-hr treatment with $1 \%$ DMSO, $10^{-5} \mathrm{M}$ retinoic acid, or $10^{-5} \mathrm{M}$ retinoic acid + $1 \%$ DMSO.

These findings indicate an association between the adhesion of differentiated HL-60 cells to tissue culture dishes and expression of integrins and OPN, an adhesion molecule considered to be instrumental in regulation of differentiation and function of many cell types, including osteoclasts. ${ }^{11}$

\section{REFERENCES}

1. Tanaka, H., E. Abe, C. Miyaura, T. Kuribayashi, K. Konno, T. Nishil \& T. SUDA. 1982. Biochem. J. 204: 713-719.

2. Martell, R. E., R. U. Simpson \& J. M. TAylor. 1987. J. Biol. Chem. 262: 5570-5575.

3. HyNES, R. O. 1992. Cell 69: 11-25.

4. Patel, V. P. \& H. T. Lodish. 1984. Science 224: 996-998.

5. Plantifaber, L. C. \& R. U. Hynes. 1989. Cell 56: 281-290.

6. Ignotz, R., J. Heino \& J. Massague. 1989. J. Biol. Chem. 264: 389-392.

7. Ferreira, O. C., J. E. Valinsky, D. Sheridan, E. A. Wayner, C. Bianco \& A. Garcia-Pardo. 1991. Exp. Cell Res. 193: 20-26.

8. Vainio, S., M. Jalkanen \& I. TheSlefF. 1989. J. Cell Biol. 108: 1945-1954.

9. Slavkin, H. C. 1990. Crit. Rev. Oral Biol. Med. 1: 1-16.

10. MacNeil, R. L. \& M. J. Somerman. 1993. J. Periodont. Res. 28: 550-559.

11. DenhardT, D. T. \& X. Guo. 1993. FASEB J. 7: 1475-1482. 